\title{
FIRST PRINCIPLES CALCULATIONS OF CARBON-NANOTUBE AND BORON-NANOTUBE BASED SINGLE ELECTRON TRANSISTORS
}

\author{
(D) Sraja Chauhan, (D) Ajay Singh Verma* \\ Department of Physics, Banasthali Vidyapith, Rajasthan, 304022, India \\ *Corresponding author: ajay phy@rediffmail.com \\ Received November 26, 2019; revised February 11, 2020; accepted February 13, 2020
}

Low power consumption, small device size and better controlled onto the charge carriers are the factors, that made Singleelectron transistor (SET) a suitable candidate for molecular electronics; yet there are some improvements that can be done in order to use it practically. The single electron transistor (SET) operates through the tunnelling of electron via two tunnel junctions. Choosing a suitable island material plays a key role in the tunnelling of electron through the tunnel junctions. In the present work, the First principle calculations of carbon-nanotube and boron-nanotube based Single-Electron Transistors have been performed. The three types of configurations of nanotubes i.e. zigzag $(5,0)$, armchair $(3,3)$ and chiral $(4,2)$, of the smallest possible diameter (approximately $4 \mathrm{~A}^{\circ}$ ), have been used. The calculations have been carried out using Atomistic toolkit (ATK-VNL) simulation package which is a density functional theory (DFT) based package. In the present work, local density approximations (LDA) as well as generalized gradient approximation(GGA) have been used to demonstrate the properties of nanotubes-based SET. These approaches have been implemented for a nanotube that is lying just above the gate dielectric. On the either side of the dielectric the electrodes are present, source in the left and drain in the right. The metallic electrodes made of gold $(\mathrm{W}=5.28 \mathrm{eV})$ and the dielectric material of the dielectric constant $10 \epsilon o$ have been used. The charging energies and additional energies of both types of nanotubes-based SET in the isolated as well as in the electrostatic environment have been calculated using the approximations. The calculated values of the charging energies in the electrostatic environment have been found to be less than the charging energies in isolated configuration that shows the renormalization of molecular energy levels. Variations of total energies against gate voltages and Charge stability diagrams (CSD) have been discussed.

KEYWORDS: Carbon Nanotube, Boron Nanotube, Single-Electron Transistor (SET), Electron Affinity, Ionization Energy, Addition Energy, Charge stability diagram (CSD)

Recent developments in the semiconductor electronics industry depict that Moore's law has become realistic as the size of storage devices decreasing day by day since past decades. Now, one can have billions of information in a small pocket, which has become possible only due to the advancement in molecular electronics. After reaching to the ultimate limit of microelectronics, for a device size of $10 \mathrm{~nm}$ or less, single-electron effects came into the existence [1-3]. Singleelectron transistors are based on the very simple Coulomb blockade principle and can control the flow of even a single electron i.e. the elementary charge.

A Single-electron transistor (SETs) is a technique by which the flow of single electron can be controlled and hence it requires very less amount of power consumption [4-11]. This device, in general, consists of three metallic electrodes i.e. source, drain and gate. In between the two electrodes, source and drain, an island (metal/semiconductor) is placed just above to the gate electrode and isolated from the gate by a thin dielectric slab. In SETs, a free electron is trapped onto the nano-meter sized island and can tunnel through it by quantum mechanical tunnelling which is known as Coulomb blockade [12-16]. Island is capacitively coupled to the electrodes by two small junctions and electron will be trapped onto the island until the energy supplied by the voltage source is greater than the coulomb energy $\left(\mathrm{e}^{2} / 2 \mathrm{C}\right)$ of the system. Gate works as a key controller in the device because by changing the gate voltage, charge on the island can be controlled. Figure 1(a) is the schematic representation of a conventional SET device while fig 1(b) represents the electrostatic model of a conventional SET device.

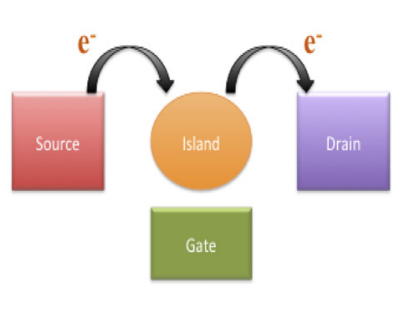

(a)

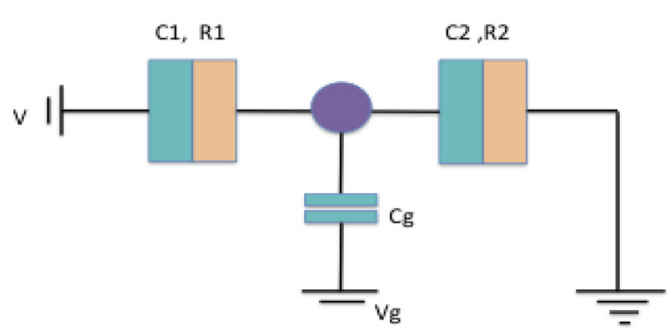

(b)

Fig. 1. (a) Schematic representation of a Single-electron transistor (SET) device.

(b)The electrostatic model of a conventional SET device. 
Nanotubes, one of the most important nano materials, have been generously studied and can be categorized into two types i.e. organic and inorganic. Organic nanotubes such as Carbon nanotubes, which were discovered by Iijima, show astonishing electrical properties and these properties depend upon the diameter and chirality [17,18], while the inorganic nanotubes similarly include boron-nitride, $\mathrm{Si}$, gold etc. [19,20,21]. Pure boron nanotubes were discovered later, and it has been predicted that all boron nanotubes are found to be metallic in nature [22-27]. In this study we have used carbon and boron nanotubes of $(5,0),(3,3)$ and $(4,2)$, i.e. zigzag, armchair and chiral configuration respectively, as island in SET. It is found that these configurations are the smallest possible nanotubes (that can be experimentally synthesized) with a diameter of about $0.4 \mathrm{~nm}$ [28]. We have used two approximations i.e. Local Density Approximation (LDA) and Generalized Gradient Approximation (GGA) to compare the carbon nanotube and boron nanotube-based transistors. Further, CNT based SET and BNT based SET has been used to study in isolated and SET configurations. Additional energies, charge stability diagrams and variations of total energies to that of the gate voltages have been calculated.

\section{COMPUTATIONAL METHODOLOGY \\ Computational details}

In order to model Single-electron transistor (SET), the basic requirement is an optimized structure, for which Density Functional Theory (DFT) based Atomistic Toolkit-Virtual Nanolab (ATK-VNL) [29] package has been used. After optimization, the modeling of SET and all calculations have been executed by using the same in which the double zeta polarized basis set are used to expand the wave functions while local density approximation (LDA) as well as Generalized Gradient Approximation (GGA) have been used [30].To design SET, parameters are chosen to be $1 \AA$, $3.4 \AA$ and $3 \AA$, which are gate electrode thickness, gate-oxide thickness, and source-drain thickness widths respectively. Dielectric material of dielectric constant 10€O [31] has been used. Source-drain and gate electrodes in SET are supposed to be of metallic type and here metal with work function $5.28 \mathrm{eV}$ [32-33] i.e. gold is considered. In device analysis, perpendicular components of electric field at the boundaries are made zero by using Neumann boundary conditions. In molecular energy spectrum, energy zero is set to absolute energy.

\section{Basic theoretical details}

Density functional theory (DFT) [34-36] is normally utilized to analyze the electronic structure of multifarious systems, holding a lot of atoms for example huge molecules or solids. It is established on electron density rather than wave functions and handles both exchange and correlation. The chief purpose of this theory is to substitute the manybody (MB) wave function with the electronic density as the essential measure. While the MB wave function is based on $3 \mathrm{~N}$ erratic, three spatial erratic for every of the $\mathrm{N}$ electrons, the density is simply a function of three erratic and is a straightforward measure to deal with both conceptually and practically. This theory has a widespread application to quantum mechanical many body problems (QMMBP), where the system of interacting electrons is mapped in an exclusive mode onto an effective non-interactive system with the same total density. Every property is therefore a functional of density. Because density decides potential; which determine Hamiltonian, energy and wave functions; from which all the properties can be determined.

The chief difficulty with DFT is that the precise functional for exchange and correlation are not recognized apart from for the free electron gas. However, approximations survive which allow the calculation of definite physical quantities fairly exactly. In physics, the majority broadly used approximation is LDA, where the functional depends only on the density at the coordinate where the functional is evaluated:

$$
E_{X C}[n]=\int \varepsilon_{X C}(n) d^{3} r
$$

Generalized gradient approximations (GGA) are immobile local but also obtain into account the gradient of the density at the similar coordinate:

$$
E_{X C}\left[n_{\uparrow}, n_{\downarrow}\right]=\int \varepsilon_{X C}\left(n_{\uparrow}, n_{\downarrow}, \nabla_{n_{\uparrow}}, \nabla_{n \downarrow}\right) d^{3} r
$$

\section{RESULTS AND DISCUSSION}

At first, we did the optimization of the nanotubes and then all six configurations [CNT $(5,0)$, CNT $(3,3)$, CNT $(4,2)$, BNT $(5,0), \operatorname{BNT}(3,3)$ and BNT $(4,2)]$ have been modeled in SET configuration using the DFT based ATK-VNL software. All calculations have been carried out using two approximations LDA and GGA. Idea behind using the two approximations was to compare the results from both the methods. In order to expand the wave functions, double zeta polarized (DZP) basis set has been used. Neumann boundary conditions, i.e. the value of electric field set to zero, have been applied. The modeled SET configuration for CNT $(5,0)$ is shown in Fig. 2, in which it can be seen that the nanotube has been placed just above the dielectric slab connected to the third i.e. gate electrode and the complete system is surrounded by the metallic electrodes. Within the metallic region, on each electrode the potential is fixed to applied bias.

After the completion of modeling, the SET configurations have been used to analyze the charge stability diagram (CSD) and variation of total energies with respect to the gate voltages. The total energies for the neutral state in SET 
environment for carbon nanotube of $(5,0),(3,3)$ and $(4,2)$ configurations are found to be $-3118.49721 \mathrm{eV},-1859.83117 \mathrm{eV}$, and $-8783.33288 \mathrm{eV}$ respectively, while for boron nanotube of $(5,0),(3,3)$ and $(4,2)$ configurations are found to be $-1540.39202 \mathrm{eV},-925.66558 \mathrm{eV},-4319.81442 \mathrm{eV}$ respectively by using LDA approximations. On the other hand, when GGA approximations are used then the total energies for the same are found to be $-3112.89942 \mathrm{eV},-1858.27950 \mathrm{eV}$, $-8763.08354 \mathrm{eV},-1535.00817 \mathrm{eV},-924.07263 \mathrm{eV}$ and $-4301.51111 \mathrm{eV}$ respectively. To calculate charging energies i.e. affinity energies and ionization energies, it is required to calculate total energies of distinct charge states $(-1,-2,0$, $1,2)$. Affinity energy, $E_{A}$, is the energy emitted/absorbed by adding one electron to the molecule on the other hand, ionization energy, $\mathrm{E}_{\mathrm{I}}$, is the energy emitted/absorbed by deducting one electron from the molecule. In equation form these may be written as follows:

$$
\begin{aligned}
& E_{A}=E^{-1}-E^{0} \\
& E_{I}=E^{+1}-E^{0}
\end{aligned}
$$

where $\mathrm{E}^{0}$ is the energy of the molecule at neutral state, $\mathrm{E}^{+1}$ is the energy of positively charged molecule and $\mathrm{E}^{-1}$ is the energy of negatively charged molecule.

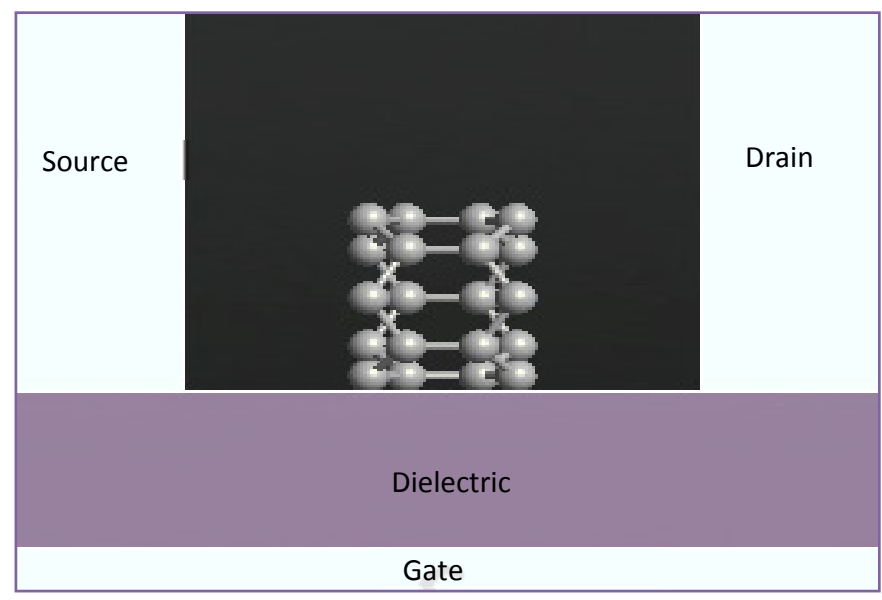

Fig. 2. SET configurations of CNT $(5,0)$

For all configurations of CNT and BNT, the calculated values of charging energies by LDA and GGA approximations are shown in the tabular form. In the table below, Table, charging energies have been calculated by using both the approximation methods for isolated configuration and for SET configuration respectively. As it is clear from the table that the value of charging energies is decreasing for most of the structures of CNT as well as for BNT from isolated to SET environment. This decrease in charging energies shows the stabilization of the charge by electrostatic surroundings.

Table.

Charging and additional energies for CNT and BNT in isolated and electrostatic surroundings

\begin{tabular}{|c|c|c|c|c|c|c|c|c|}
\hline \multirow{8}{*}{ ISO } & & & & $\overline{\mathrm{LDA}}$ & & & $\mathrm{GG}_{\mathrm{t}}$ & \\
\hline & & & $\mathrm{E}_{\mathrm{I}}(\mathrm{eV})$ & $\mathrm{E}_{\mathrm{A}}(\mathrm{eV})$ & $\mathrm{E}_{\mathrm{ADD}}=\mathrm{E}_{\mathrm{A}}-\mathrm{E}_{\mathrm{I}}(\mathrm{eV})$ & $\mathrm{E}_{\mathrm{I}}(\mathrm{eV})$ & $\mathrm{E}_{\mathrm{A}}(\mathrm{eV})$ & $\mathrm{E}_{\mathrm{ADD}}=\mathrm{E}_{\mathrm{A}}-\mathrm{E}_{\mathrm{I}}(\mathrm{eV})$ \\
\hline & \multirow{3}{*}{ CNT } & $(5,0)$ & 5.59236 & -2.96275 & -8.55511 & 5.51546 & -2.93499 & -8.45045 \\
\hline & & $(3,3)$ & 7.35366 & -0.86581 & -8.21947 & 7.29691 & -0.8811 & -8.17801 \\
\hline & & $(4,2)$ & 4.92968 & -2.79152 & -7.7212 & 4.8809 & -2.74619 & -7.62709 \\
\hline & \multirow{3}{*}{ BNT } & $(5,0)$ & 6.30343 & -3.79847 & -10.1019 & 6.23544 & -3.73954 & -9.97498 \\
\hline & & $(3,3)$ & 8.86497 & -5.02667 & -13.89164 & 8.75737 & -5.00505 & -13.76242 \\
\hline & & $(4,2)$ & 5.88888 & -5.02643 & -10.91531 & 5.77556 & -4.9287 & -10.70426 \\
\hline \multirow{6}{*}{ SET } & \multirow{3}{*}{ CNT } & $(5,0)$ & 6.47731 & -4.93234 & -11.40965 & 6.50309 & -4.55857 & -11.06166 \\
\hline & & $(3,3)$ & 6.26139 & -4.35388 & -10.61527 & 6.29442 & -4.37368 & -10.6681 \\
\hline & & $(4,2)$ & 5.35121 & -5.02946 & -10.75916 & 5.44697 & -5.14483 & -10.5918 \\
\hline & \multirow{3}{*}{ BNT } & $(5,0)$ & 5.87573 & -4.5 & -10.37573 & 5.87078 & -4.43984 & -10.31062 \\
\hline & & $(3,3)$ & 7.19601 & -2.14373 & -9.33974 & 6.86654 & -3.14544 & -10.01198 \\
\hline & & $(4,2)$ & 5.43252 & -4.50399 & -10.35896 & 5.4218 & -4.89782 & -10.31962 \\
\hline
\end{tabular}
by using both the approximation.

Improvement in the conductance can be observed by calculating the additional energy, which is the difference of affinity energy $\left(E_{A}\right)$ and ionization energy $\left(E_{I}\right)$,

$$
\mathrm{E}_{\mathrm{Add}}=\mathrm{E}_{\mathrm{A}}-\mathrm{E}_{\mathrm{I}}
$$


From the Table it can be seen that there is a remarkable decrease of the additional energies for SET environment of CNT $(5,0)$, CNT $(3,3)$ and CNT $(4,2)$ structures for both the approximations used. Decrease in additional energy shows the stabilization of the charges in the structures. A very small reduction is seen for the BNT $(5,0)$, while for BNT $(3,3)$ and BNT $(4,2)$ values of energies are not decreasing. This may happen due to the instability of the structures. From the table it is also clear that CNT $(5,0)$ has the lowest additional energy among all the configurations. Also, it is clear that by using LDA, we are obtaining the lowest energy for the same. On the other hand, by using GGA, we are obtaining the lowest energy for armchair type CNT i.e. $(3,3)$. While in the case of boron nanotube [20-22], we are obtaining good results for BNT $(5,0)$ by using GGA method.
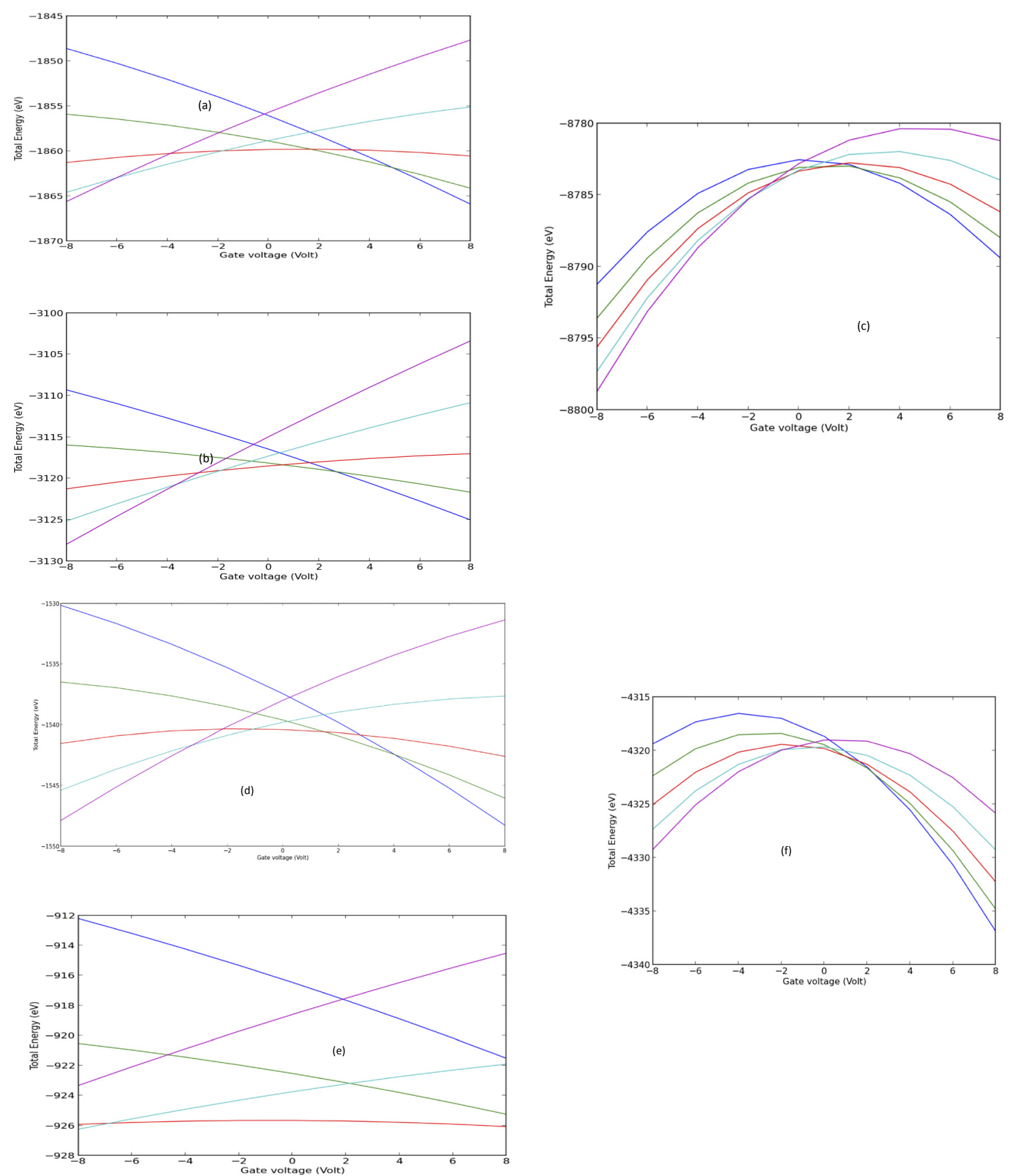

Fig. 3. Variation of total energies against gate voltage by using LDA

(a) - CNT $(5,0),($ b) - CNT(3,3), (c) - CNT(4,2), (d) - BNT(5,0), (e) - BNT(3,3), (f) - BNT4,2)

Fig. 3 and 4 show the variation of total energies [by considering LDA (Fig.3) and by GGA (Fig.4)] with respect to gate voltages for distinct charge states in which different color map is used i.e. blue (-2), green (-1), red (0), turquoise (1), and violet (2). Different color map depicts different charge state. From the fig. 3 it is clear that for CNT $(5,0), \mathrm{CNT}(3,3)$, $\operatorname{BNT}(5,0)$, and BNT $(3,3)$ configurations, the system has minimum energy in the neutral state i.e. 0 charge state. Since 0 charge state represents the stability of any system therefore the system is stable in zero charge state. One more thing that can be noted from the Fig. 3 is that when a negative bias is applied then positive states are getting stable. This indicates 
the fact that on applying negative biasing, gate will be negatively biased, and an electron will be eliminated from the CNT/BNT and making it positively charged.

As a result, the HOMO level of CNT/BNT appears to be above the electrode's Fermi level. At the same time, when positive bias is applied then negative charge states are getting stable. This indicates that when positive bias is applied, gate will be positively charged then an electron is attracted towards CNT/BNT and making it negatively charged. As a result, the LUMO level of CNT/BNT appears to be above the electrode's Fermi level. Configuration $(4,2)$ is not showing that much promising stabilization properties as from both the Fig. 3 and Fig. 4 it is clear that system is not so stable in their neutral state as the minimum energy of the system is not for the zero-charge state.

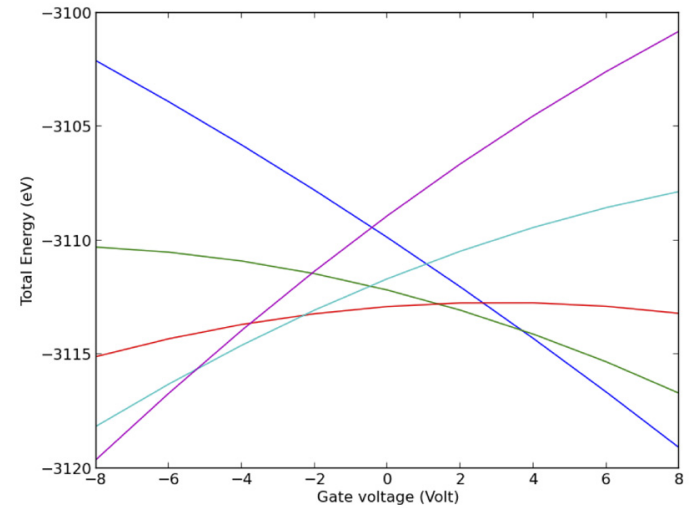

(a)

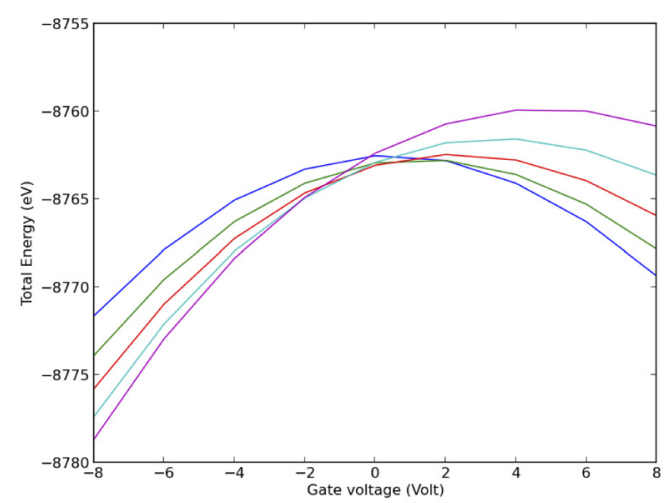

(c)

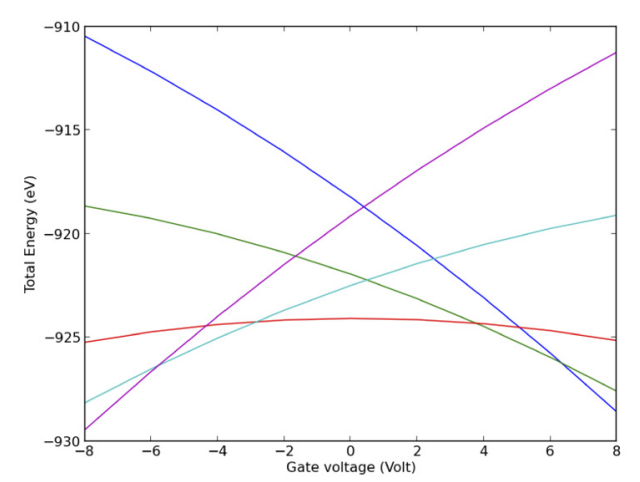

(e)

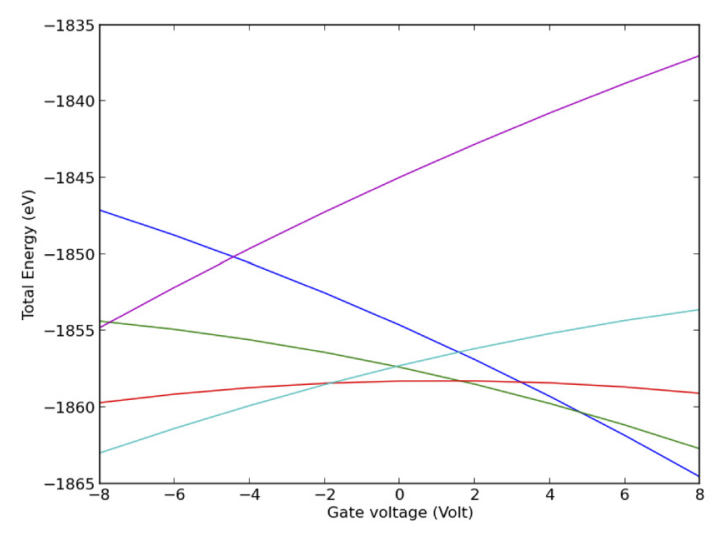

(b)

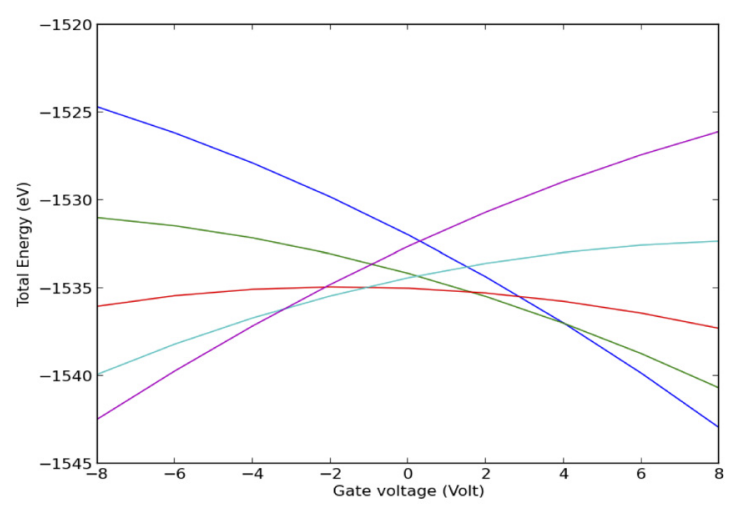

(d)

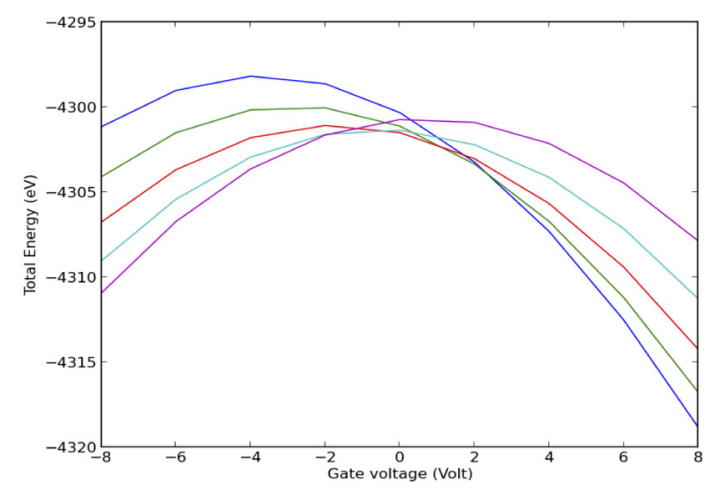

(f)

Fig. 4. Variation of total energies against gate voltage by using GGA

(a) - CNT (5,0), (b) - CNT $(3,3)$, (c) - CNT $(4,2)$, (d) - BNT $(5,0)$, (e) - BNT $(3,3)$, (f) - BNT $(4,2)$

Charge stability diagrams (CSD) have been plotted for the investigation of conductance and are shown in Fig. 5 and Fig. 6 [by using LDA and GGA respectively]. CSD explains the dependence of conductance on the source-drain and voltage. In this diagram, for different gate voltages the charging energies of CNT/BNT in SET surroundings have been plotted. A certain number of energy levels i.e. charge states are present for a fixed value of source-drain and gate voltage. Different colors represent the different energy levels i.e. blue (0), light blue (1), green (2), orange (3) and red (4) in CSD 
and conductance depends upon the number of charge states in bias window. As much as the width of the central dark region decreases, less the charging energy will be needed to bring SET into conduction state.

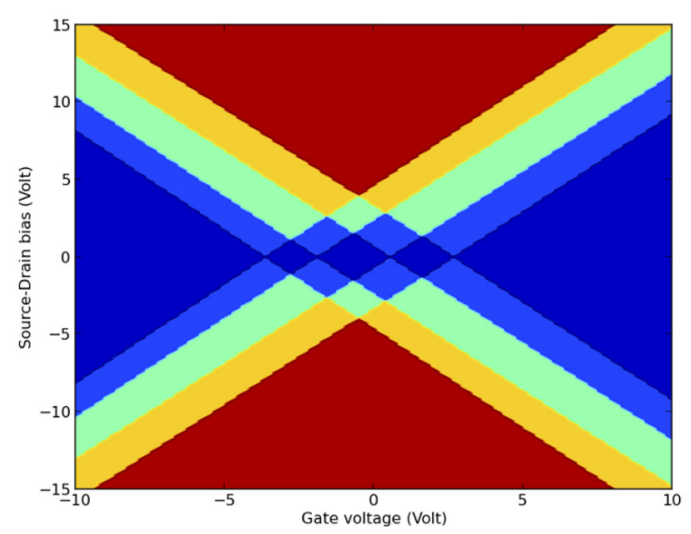

(a)

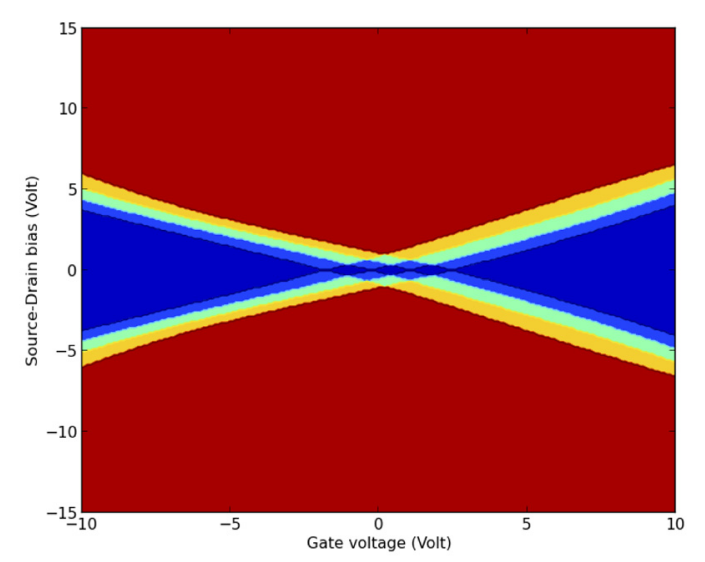

(c)

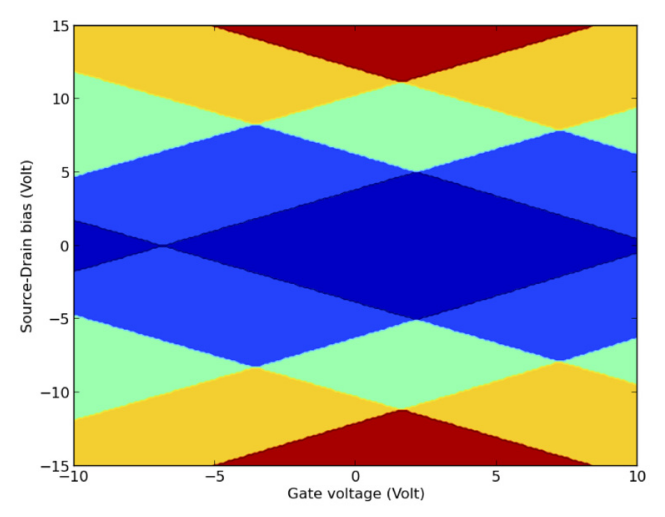

(e)

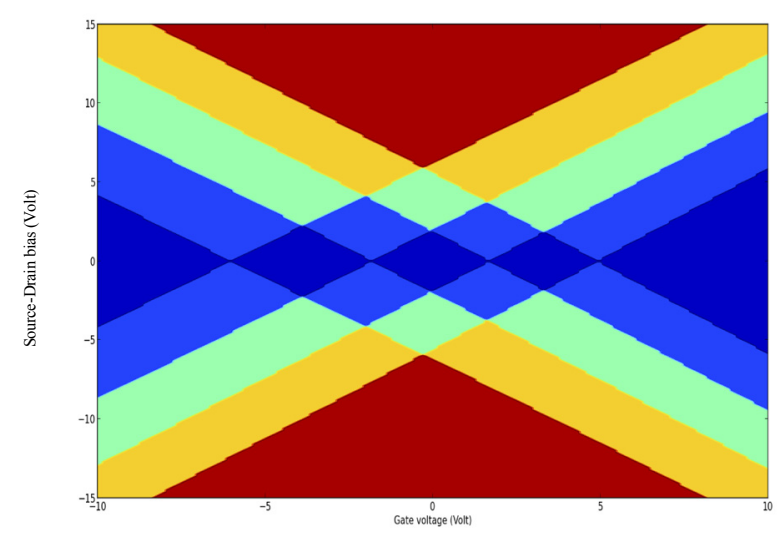

(b)

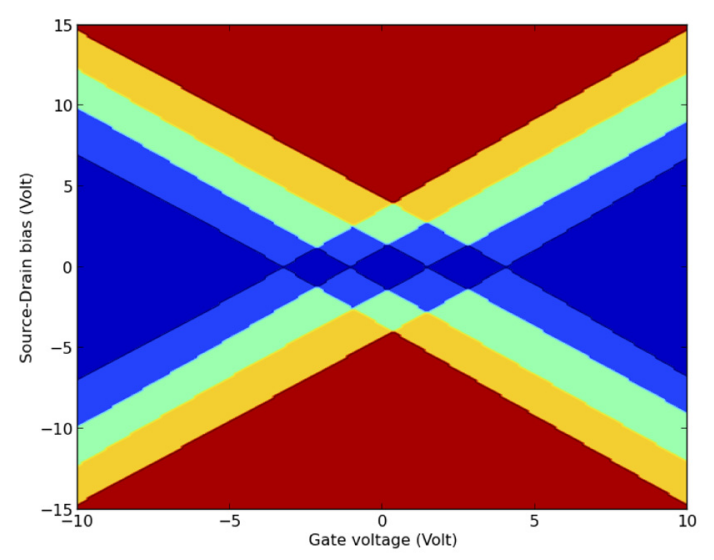

(d)

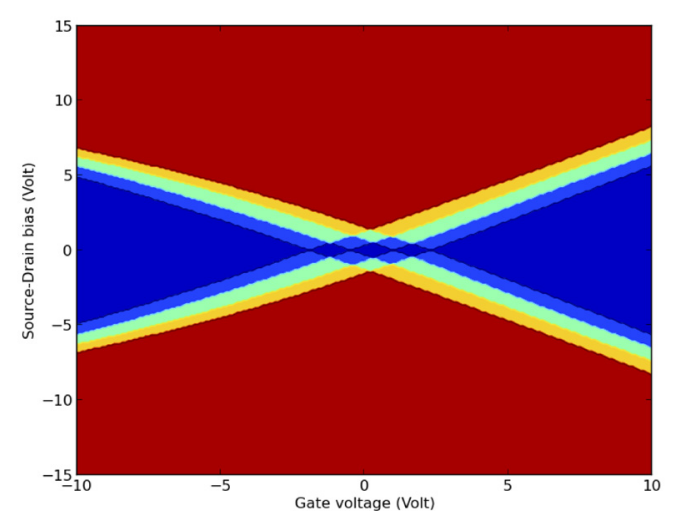

(f)

Fig. 5. Charge stability diagram (CSD) for CNT_SET (a,b,c) and BNT_SET (d,e,f)

CSD shows different number of charge states for different bias with blue (0), light blue (1), green (2), orange (3) and red (4) [by considering LDA]

From the Fig. 5 and Fig. 6 it can be shown that central dark blue region is minimum for CNT $(5,0)$ when calculations are done using LDA. On the other hand, when GGA method has been used to calculate total energies, BNT $(5,0)$ is showing the minimum dark blue region. As much as the width of the central dark region decreases, less the charging energy will be needed to bring SET into conduction state. If we compare all the devices structures, calculating by using LDA as well as GGA, then we can state that CNT $(5,0)$ by calculating LDA is showing better results because it has the minimum charging energy and the smaller coulomb blockade region among all other candidates, i.e. for this configuration electron is trapped in the coulomb diamond for a less time as compared to other configurations. Since the charging energy is the amount of energy that is required for an electron to tunnel through the tunnel junction, so it can increase the amount of the current flow and can make the SET operation fast. 


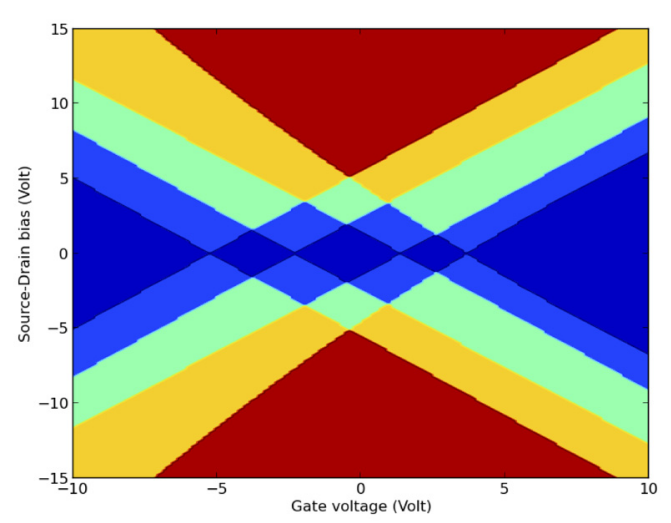

(a)

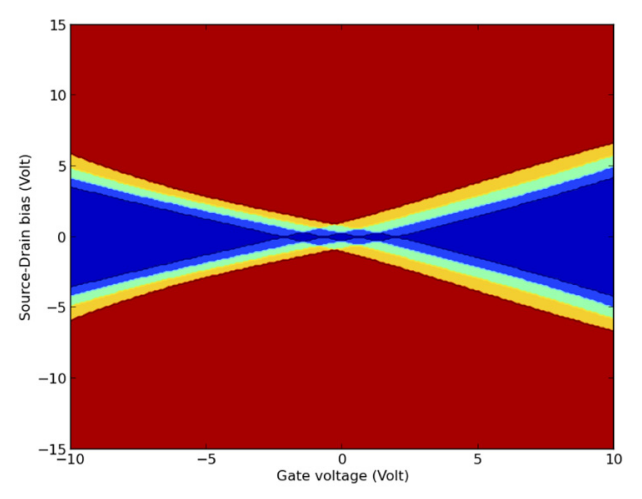

(c)

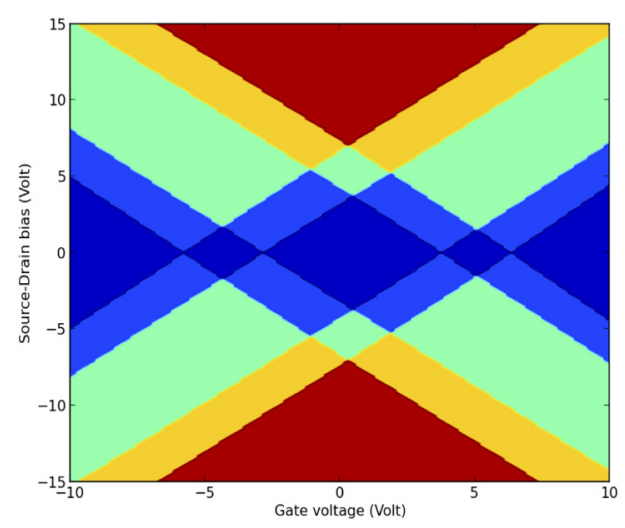

(e)

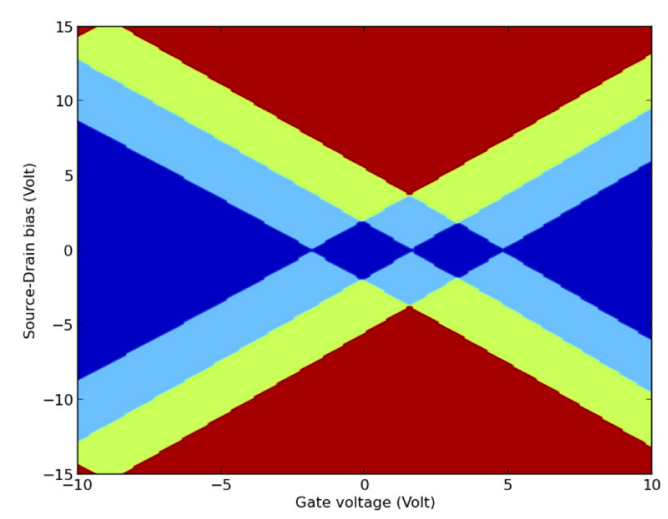

(b)

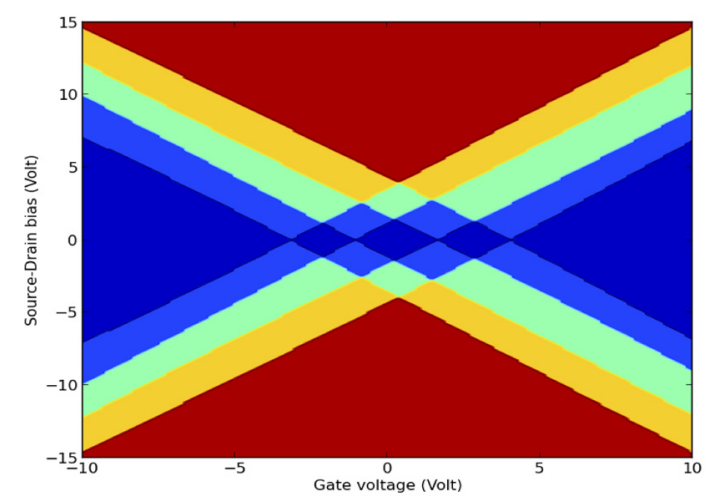

(d)

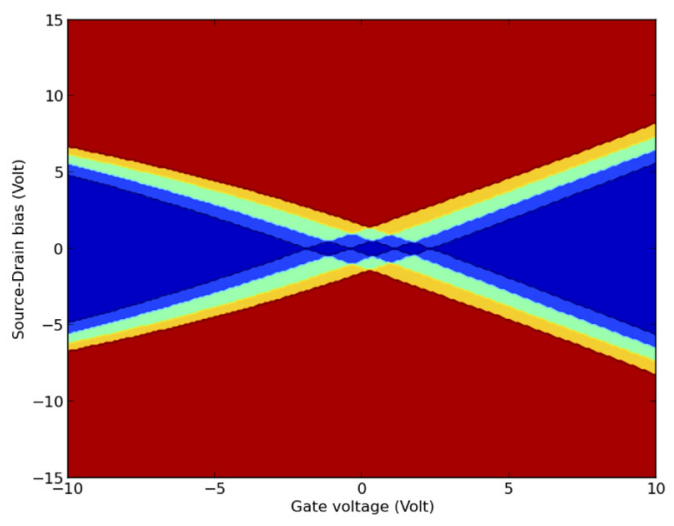

(f)

Fig. 6. Charge stability diagram (CSD)for CNT SET (a,b,c) and BNT SET (d,e,f)

CSD shows different number of charge states for different bias with blue (0), light blue (1), green (2), orange (3) and red (4)

[by considering GGA]

\section{CONCLUSIONS}

In the present work, the calculations exhibit the application of DFT to obtain the perceptivities into the different properties of nanotubes based Single-Electron Transistor working in a Coulomb blockade regime. SETs with the different islands i.e. carbon nanotube and boron nanotube have been modelled and compared for their conductivity and fast switching property with the help of charge stability diagram (CSD) and the variation of the total energies against gate voltage for different states of charges. Due to the stabilization of the charges, the charging energies have decreased for electrostatic surroundings. Addition energy for the island $\operatorname{CNT}(5,0)$ has been found to be the lowest for electrostatic environment. Charge stability diagrams (CSD) have been compared and suggest CNT $(5,0)$ for better performance and fast switching properties for the area of the coulomb blockade region is reduced as compared to other islands, therefore for this island less amount of energy is needed to bring SET in the ON state. Therefore, nanotubes-based SETs have been successfully modelled and studied by both the approximation methods and we found the good results from LDA for the island CNT $(5,0)$. 


\section{ACKNOWLEDGMENT}

This study has been carried out successfully through the financial support from MHRD FAST Programme (grant no. 5-5/2014TS.VII), Govt. of India and DST, India under CURIE program (grant no. SR/CURIE- Phase-III/01/2015(G)).

\section{ORCID IDs}

(1) Sraja Chauhan https://orcid.org/0000-0002-7055-8574, (DAjay Singh Verma https://orcid.org/0000-0001-8223-7658

\section{REFERENCES}

[1] D. Darau, G. Begemann, A. Donarini, M. Grifoni, M. Grifoni, Physics Review B, 79(23), 235404 (2009), https://doi.org/10.1103/PhysRevB.79.235404.

[2] T.A. Gschneidtner, Y.A. Diaz Fernandez and K. Moth-Poulsen, Progress in self-assembled single-molecule electronic devices, J. Materials Chemistry C, 1(43), 7127 (2013), https://doi.org/10.1039/C3TC31483A.

[3] The Chip that Jack Built, Texas Instruments, accessed May 29, 2008.

[4] G. Fiori, M. Pala and G. Iannaccone, IEEE Transactions on Nanotechnology, 4(4), 415-421 (2005), https://doi.org/10.1109/TNANO.2005.851284.

[5] A. Chen, J. Hutchby, V. Zhirnov and G. Bourianoff, Emerging Nanoelectronics Devices, (John Wiley \& Sons, 2015 ), pp. 540.

[6] J. Wu, J. Min and Y. Taur, IEEE Transactions on Electron Devices", 62(9), 3019-3024 (2015), https://doi.org/10.1109/TED.2015.2458977.

[7] C. Bäuerle, D.C. Glattli, T. Meunier, F. Portier, P. Roche, P. Roulleau and X. Waintal, Reports on Progress in Physics, 81(5), 056503 (2018), https://doi.org/10.1088/1361-6633/aaa98a.

[8] J. Jalil, Y. Zhu, C. Ekanayake and Y. Ruan, Nanotechnology, 28(14), 142002 (2017), https://doi.org/10.1088/1361-6528/aa57aa.

[9] S.I. Garduño, A. Cerdeira, M. Estrada, J. Alvarado, V. Kilchystka and D. Flandre, J. Applied Physics, 109, 084524 (2011), https://doi.org/10.1063/1.3575324.

[10] K.K. Likharev, Proceedings of the IEEE, 87, 606-632 (1999), https://doi.org/10.1109/5.752518.

[11] M.L. Perrin, B. Enrique and H.S.J. van der Zant, Chemical Society Reviews 44, 902- 919 (2015), https://doi.org/10.1039/C4CS00231H.

[12] Y. Takahashi, Y. Ono, A. Fujiwara and H. Inokawa, J. Physics. Condensed Matter, 14, 995-1033 (2002), https://doi.org/10.1088/0953-8984/14/39/201.

[13] V.K. Hosseini, M.T. Ahmadi, S. Afrang and R. Ismail, J. Electron. Mater. 46(7), 4294-4298 (2017), https://doi.org/10.1007/s11664-017-5354-7.

[14] V.V. Shorokhov, D.E. Presnov, S.V. Amitonov, Y.A. Pashkin and V.A. Krupenin, Nanoscale, 9, 613-620 (2017) https://doi.org/10.1039/C6NR07258E.

[15] F. Wang, J. Fang, Sh. Chang, Sh. Qin, X. Zhang, H. Xu, Physics Letters A, 381, 476-480 (2017), https://doi.org/10.1016/j.physleta.2016.11.015.

[16] V. Khadem Hosseini, M T. Ahmadi, S. Afrang and R. Ismail, J. Electron. Mater. 46, 4294-4298 (2017), https://doi.org/10.1007/s11664-017-5354-7.

[17] Z.A.K. Durrani, Single-electron devices and circuits in silicon, (Imperial College Press, London, 2010).

[18] F. Willy and Y. Darma, J. Physics: Conference Series, 739, 012048 (2016), https://doi.org/10.1088/1742-6596/739/1/012048.

[19] K. Seike, Y. Kanai, Y. Ohno, K. Maehashi, K. Inoue and K. Matsumoto, Japanese Journal of Applied Physics, 54, 06FF05 (2015), https://doi.org/10.7567/JJAP.54.06FF05.

[20] X. Yang, Y Ding and J. Ni, Physics Review B, 77, 041402(R), (2008), https://doi.org/10.1103/PhysRevB.77.041402.

[21] D. Zhang, R. Zhu and C. Liu, J. Mater. Chem., 16, 2429-2433, (2006), https://doi.org/10.1039/B517480E.

[22] A. Quandt and A.Y. Liu and I. Boustani, Physical Review B, 64, 125422 (2001), https://doi.org/10.1103/PhysRevB.64.125422.

[23] D. Ciuparu, R.F. Klie, Y. Zhu and L. Pfefferle, J. Physical Chemistry B, 108, $3967-3969$ (2004), https://doi.org/10.1021/jp049301b.

[24] A. Quandt and I. Boustani, Chem. Phys. Chem. 6, 2001-2008 (2005), https://doi.org/10.1002/cphc.200500205.

[25] V. Bezugly, J. Kunstmann, B. Grundkotter-Stock, T Frauenheim, T. Niehaus and G. Cuniberti, ACS Nano 5, $4997-5005$ (2011), https://doi.org/10.1021/nn201099a.

[26] F. Liu, C. Shen, Z. Su, X. Ding, S. Deng, J. Chen, N. Xuand and H. Gao, Jour. Mater. Chem. 20, $2197-2205$ (2010), https://doi.org/10.1039/B919260C.

[27] V. Bezugly, J. Kunstmann, B. Grundkotter-Stock, T. Frauenheim, T. Niehaus and G. Cuniberti, ACS Nano, 5, 4997-5005 (2011), https://doi.org/10.1021/nn201099a.

[28] L.C. Qin, X. Zhao, K. Hirahara, Y. Miyamoto, Y. Ando and S. Iijima, Nature, 408, 50 (2000), https://doi.org/10.1038/35040699.

[29] Atomistic Toolkit-Virtual Nanolab. Quantum wise A/S, http://quantumwise.com/

[30] M. Brandbyge, J.L. Mozos, P. Ordejón, J. Taylor and K. Stokbro, Physical Review B, 65, 165401 (2002), https://doi.org/10.1103/PhysRevB.65.165401.

[31] J. Robertson, The European Physical Journal-Applied Physics, 28, 265-291 (2004), https://doi.org/10.1051/epjap:2004206.

[32] Synopsys Inc. Mountain, CA94043, http://docs.quantumwise.com/tutorials/work_function_ag_100/work_function_ag_100.html.

[33] K.I. Hashim, J. Applied Mathematics and Physics, 6, 1324-1331 (2018), https://doi.org/10.4236/jamp.2018.66111.

[34] K. Capelle, Brazillian Journal of Physics, 36, 1318-1343 (2006), http://dx.doi.org/10.1590/S0103-97332006000700035.

[35] R. Nityananda, J. Science Education, 22(8), 809-811 (2017), https://doi.org/10.1007/s12045-017-0529-3.

[36] U. Mordovina, T. E. Reinhard, I. Theophilou, H. Appel and A. Rubio, J. Chemical Theory and Computation, 15, 5209-5220 (2019), https://doi.org/10.1021/acs.jctc.9b00063. 


\section{ПЕРШОПРИНЦИПИ РОЗРАХУНОКУ ОДНОЕЛЕКТРОННИХ ТРАНЗИСТОРІВ \\ НА НАНОТУБКАХ ВУГЛЕЦЮ ТА БОРУ \\ Сраджа Чаухан, Аджай Сінгх Верма}

Кафедра фізики, Банасталі Від'япіт, Раджастан, 304022, Індія.

Низьке споживання енергії, невеликий розмір пристрою та краща керованість носіїв заряду - це фактори, які зробили одноелектронний транзистор (SET) придатним кандидатом для молекулярної електроніки, але є деякі вдосконалення, які можна зробити для його практичного використання. Одноелектронний транзистор (SET) працює на основі тунелювання електронів через два тунельних переходи. Вибір відповідного острівного матеріалу відіграє ключову роль у тунелюванні електронів через тунельні переходи. В даній роботі виконані розрахунки першопринципів одноелектронних транзисторів на основі вуглецевих та нанотрубок на основі бору. Використовували три типи конфігурацій нанотрубок, тобто зигзаг $(5,0)$, крісло $(3,3)$ та хіральний тип $(4,2), 3$ найменшим можливим діаметром (приблизно $\left.4 \mathrm{~A}^{\circ}\right)$. Розрахунки проводилися за допомогою пакету моделювання Atomistic Toolkit (ATK-VNL), який є пакетом на основі теорії функціональної щільності (DFT). У цій роботі для демонстрації властивостей SET на основі нанотрубок використовується наближення локальної щільності (LDA), а також узагальнене наближення градієнта (GGA). Ці підходи були реалізовані для нанотрубок, що лежать трохи вище діелектричного затвору. По обидва боки діелектрика присутні електроди, джерело ліворуч і стік справа. Використовувались металеві електроди із золота $(\mathrm{W}=5,28 \mathrm{eB})$ та діелектричного матеріалу з діелектричною сталою $10 \epsilon o$. Енергії зарядки та додаткові енергії обох типів SET на основі нанотрубок як в ізольованому, так і в електростатичному середовищі були розраховані за допомогою наближень. Обчислені значення енергій заряджання в електростатичному середовищі виявились меншими, ніж енергії заряджання в ізольованій конфігурації, що показує перенормування рівнів молекулярної енергії. Обговорено варіації загальної енергії від напруги на затвору та діаграми стійкості заряду (CSD).

КЛЮЧОВІ СЛОВА: нанотрубка вуглецю, нанотрубка бору, одноелектронний транзистор (SET), спорідненість електронів, енергія іонізації, енергія додавання, діаграма стійкості заряду (CSD)

\section{ПЕРВОПРИНЦИПЫ РАСЧЕТА ЭЛЕКТРОННЫХ ТРАНЗИСТОРОВ НА НОТРУБКАХ ИЗ УГЛЕРОДА И БОРА Сраджа Чаухан, Аджай Сингх Верма}

Физический факультет, Banasthali Vidyapith, Раджастхан, 304022, Индия

Низкое потребление энергии, небольшой размер устройства и лучшая управляемость носителей заряда - это факторы, которые сделали одноэлектронный транзистор (SET) пригодным кандидатом для молекулярной электроники, но есть некоторые усовершенствования, которые можно сделать для его практического использования. Одноэлектронный транзистор (SET) работает на основе туннелирования электронов через два туннельных перехода. Выбор соответствующего островного материала играет ключевую роль в туннелировании электронов через туннельные переходы. В данной работе выполнены расчеты первопринципов одноэлектронных транзисторов на основе нанотрубок углерода и бора. Использовали три типа конфигураций нанотрубок, то есть зигзаг $(5,0)$, кресло $(3,3)$ и хиральный тип $(4,2)$, с наименьшим возможным диаметром (примерно 4A). Расчеты проводились с помощью пакета моделирования Atomistic Toolkit (ATK-VNL), который является пакетом на основе теории функциональной плотности (DFT). В этой работе для демонстрации свойств SET на основе нанотрубок используется приближения локальной плотности (LDA), а также обобщенное приближение градиента (GGA). Эти подходы были реализованы для нанотрубок, лежащих чуть выше диэлектрического затвора. По обе стороны диэлектрика присутствуют электроды, источник слева и сток дело. Использовались металлические электроды из золота $(\mathrm{W}=5,28$ эВ) и диэлектрического материала с диэлектрической постоянной 10во. Энергии зарядки и дополнительные энергии обоих типов SET на основе нанотрубок как в изолированном, так и в электростатическом среде были рассчитаны с помощью приближений. Вычисленные значения энергий подзарядки в электростатической среде оказались меньшими, чем энергии подзарядки в изолированной конфигурации, что показывает перенормировку уровней молекулярной энергии. Обсуждены вариации общей энергии от напряжения на затворе и диаграммы устойчивости заряда (CSD).

КЛЮЧЕВЫЕ СЛОВА: углеродная нанотрубка, нанотрубка бора, одноэлектронный транзистор (SET), сродство к электрону, энергия ионизации, добавочная энергия, диаграмма стабильности заряда (CSD). 